\title{
Thede Kahl, Johannes Kramer \& Elton Prifti (Hg.), Romanica et Balcanica. Wolfgang Dahmen zum 65. Geburtstag ("Jenaer Beiträge zur Romanistik", 7), Akademische Verlagsgemeinschaft, München, 2015, XXV + 795 p.
}

\author{
Dinu Moscal* \\ “A. Philippide” Institute of Romanian Philology, Str. Th. Codrescu 2, 700481 Iași, Romania
}

The seventh volume of the series "Jenaer Beiträge zur Romanistik" is dedicated to the acknowledged Romanist Wolfgang Dahmen, whose contributions identify him first of all as an expert in Romanian studies, as shown by the list of publications included in the first pages of the volume (p.XI-XXV). Moreover, the percentage of Romanian studies, as well as their being positioned in the first part of the volume sections, indicate the same aspect. Those who know the author are undoubtedly aware that his area of interest is much larger, an aspect that is generously supported by the above mentioned list of publications. The volume is structured in three sections: one containing biographic and at the same time historic references pertaining mainly to the field of Romance studies, entitled Annäherungen (p. 344), followed by two scientific sections, Sprachwissenschaft (p. 47-395) and Kulturwissenschaft / Literaturwissenschaft (p. 399-795).

The first in the line of four contributions of the first section, entitled Alten Kameraden beim Marsch durch die Romania oder Doi filologi de școală veche (p. 3-25), belongs to another renowned Romanist, Johannes Kramer, who has stood besides Wolfgang Dahmen ever since the beginning of the his latter's career in the field of Romance studies and together with whom he founded the new series of the "BalkanArchiv" review (beginning with the year 1976). His contribution provides an all encompassing image of Romance studies from the perspective of scientific events and publications, as well as the specialists involved beginning with the '70s and even earlier. The second part of the title relates directly to Caragiale's play Un pedagog de școală nouă, by depicting the "outdated" method of formation of a authentic philologist. This first contribution is followed by two poems by Aromanian poet Kira Iorgoveanu-Mantsu, and a contribution of his friend from Iași, Eugen Munteanu, entitled Wolfgang sive de amicitia (p. 3135), with autobiographical touches. The fourth contribution belongs to Anton Sterbling (known to the Romanian public also due to his quality as founding member of "Aktionsgruppe Banat"), Wie treffe ich das fremde Wort... (p. 37-45), which points out to other areas of expertise of the Romanist Wolfgang Dahmen, his being labeled a "linguist" being regarded as a disparagement in relation to the topics of his publications. Inspired by the model of the one this volume is dedicated to, the German sociologist-a Banat Swabian who fled Romania at the age of 22-proposes his German language readers a few of his own translations from Lucian Blaga's Antologia de poezie populară [Anthology of Folk Poetry] compared with the translations in the bilingual edition published in 1995 by the "Grai și Suflet" Publishing House.

The second section is opened by an acknowledged specialist in Romance and Romanian study, Eugenio Coseriu's disciple, Rudolf Windisch, with an analysis of traces of vulgar Latin in the Roman inscriptions found on the territory of the Roman province Dacia, namely the military diplomas and waxed plates: Vulgärlateinische Spuren in den Inscriptiones Dacia et Scythia Minoris Antiqua? (p. 47-65). The basic linguistic corpus is extracted from the work mentioned in the title, but it refers as well to the well-known series Inscripțile Daciei Romane [Inscriptions from Roman Dacia], mostly coordinated and edited by the same I.I. Russu, in collaboration with D.M. Pippidi. The main objective consists in the identification of graphic-phonetic and morphologic "errors" along with the lexical particularities of Latin in the Romance Oriental lateral area. In this context the author also discusses data

\footnotetext{
*Email address: dinumoscal@yahoo.com.
} 
and information related to the administrative system, as well as topographic issues. An equally important topic is the accurate appreciation of the contributions of I.I. Russu, motivated by the opinions of Géza Alföldy who stated that the author did not meet the expectations of specialists and that he had not consulted previous research in the field. The Romanist Windisch proves that I.I. Russu was not only an epigraphist and archæologist, but also a reputed specialist in the history of languages and even Romance linguists can benefit from his works. Readers who are interested in this contribution can access its first version in "Anuarul de lingvistică și istorie literară" (volume LII, p. 39-54).

Petar Atanasov, complete Romanist and reputed specialist in Romanian studies acknowledged mostly for his contributions regarding the MeglenoRomanian dialect, provides an excellent synthesis of the history of Aromanians and Megleno-Romanians ("Aromâni şi meglenoromâni: trecut și prezent [Aromanians and Megleno-Romanians: Past and Present], p. 81-96), where he approaches both language (the patrimony, the language) and cultural, historic, and geographic issues in a synthesis concluded with a few perspective observations on language. An important section of this synthesis is the one entitled Limbi sau dialecte [Languages or Dialects], providing a short account of the realities that indicate the status of "diverging historic dialects of the Romanian language" (p. 92) for the two Romanian Southern Danubian dialects, obviously valid for the Istro-Romanian dialect, as well. These findings (not observations) coming from a specialist in Romanian and Balkan studies whose competences are beyond any doubt should be taken into account by one of the editors of this volume who employs in his studies the collocation "Aromanian language". Moreover, in the field of Romance Studies, where linguistic criteria represent a priority, Aromanian, Megleno-Romanian and Istro- Romanian can solely be regarded as dialects. While such inaccuracy (resulting from the absolutization of certain criteria of an extralinguistic nature) can be overlooked with the above-mentioned editor, since he is not specialized in linguistics and tends to show a bias towards social-political aspects, it is a lot harder to find justifications, from the perspective of a long tradition in which scientific truth should prevail, for the Romanist Michael Metzeltin (sometimes co-author with Thede Kahl), who ignores, for one reason or another, the realities pointed at here by Petar Atanasov.

In the same section, we remark the contribution of Otto Winkelmann, Moderne RumänischGrammatiken im Vergleich (p. 105-137), in which the author presents the history and particularities of Romanian grammars between the years 19872013, namely from the last Romanian grammaticography written by A. Turculet, the Romanian researcher from Iaşi, to the present date. After a general presentation of the grammars-firstly the ones written in Romanian and then the ones written in other languages - and after mentioning those grammars that have not been discussed yet, the author presents in more detail Gramatica de bază a limbii române [The Basic Grammar of the Romanian Language] (2011), coordinated by Gabriela Pană Dindelegan, Rumänische Grammatik (2013), elaborated by Maria Iliescu and Victoria Popovici, as well as Romanian. An Essential Grammar (2008), elaborated by Ramona Gönczöl-Davies. Undoubtedly, of all these grammars he describes in detail, the author is most appreciative of Gramatica de bază a limbii române [The Basic Grammar of the Romanian Language] (p. 123), which is naturally favoured, as it represents the concentrated version of the Romanian Academy grammar. We mention in this context one of the grammars described concisely, belonging to Dumitru Irimia (Gramatica limbii române [Romanian Language Grammar]), the last edition of which (2008) was conceived by contrasting it with the Romanian Academy grammar. Rumänische Grammatik is dedicated not only a detailed presentation, but also a history of its elaboration. One of the observations refers to the examples that are mainly created by the author or selected from the internet, a practice that hardly corresponds to the Romanian grammars tradition. In contrast to this, Dumitru Irimia's grammar mentioned above, due to the fact that its author was an acknowledged specialist in poetics, stylistics and Eminescology exemplifies functions and relations with quotations from the Romanian literature, often taken from Eminescu's work. However, the fact that examples from literature were abandoned in Praktische Grammatik der rumänischen Sprache should be understood in relation to the objective of this grammar: the access of German speakers to the spoken Romanian language. For this very reason this 
grammar pays great attention to speech registersstandard, common and popular-even if a clear-cut distinction between the last two registers is difficult to establish. In terms of specific traits of the grammar for English speakers, Romanian. An Essential Grammar, one notes the issue of phonemes that are nonexistent in English ( $\breve{a}$ and $\hat{\imath})$, the diphtongues and the vowel or consonant alternation in the flection, the attempt to find relatively regular conjugations by subdifferentiations within the four conjugations commonly accepted in Romanian grammars, the focus on spoken language norm depending on formal registers. The closing remarks attempt at depicting the characteristics of contemporary Romanian grammars, the first indicated characteristic being the lack of homogeneity especially in grammars elaborated by teams of authors, of which the Romanian Academy Grammar is no exception. The attempt to stand in line with the newest syntactic theories, the lack of relevance for the contemporary spoken language of examples extracted from the $19^{\text {th }}$ century literature, the absence of a clear perspective upon linguistic variation and the oscillation between descriptive and prescriptive approaches are viewed as issues for which Romanian grammars can only hope to find complete answers in the future.

The other contributions in the field of Romanian studies comprised in the first part of the second section include a discourse analysis in the first complete translation of the Septuagint into Romanian, an analysis relying on the last edition of the Romanian Academy grammar (2008), a presentation of the Romanian suffix -ciune, a presentation of nicknames, in the broadest sense, in the Romanian football world, as well as an exquisite analysis of street names in Timișoara, with an emphasis of the changes they underwent along different historical and political contexts (Holger Wochele, Straßennamen in Rumänien am Beispiel von Hermannstadt/Sibiu, p. 151-168).

The article that makes the passage from Romanian studies towards the other Romance languages and languages from the Balkan areacompleted by few contributions on general topics or pertaining to languages outside the afore-mentioned framework-is entitled Sprachgeographische Konstellationen: Sardisch-Süditalienisch-Rumänisch ( $\mathrm{p}$. 169-179). The author, Ian Reinhardt, renders a brief account of the correspondences within the common lexis inherited in the three Romance idioms, starting from the contributions of Gerhard Rohlfs and the well-known lexicographic materials REW and DÉRom.

There follows a study dedicated to Sephardi, «Ich kann singen, aber nicht sprechen»: Die sephardische Renaissance auf der Bühne (p. 181-214), in which the author, Ioana Nechiti, approaches from a sociolinguistic perspective the rather artificial revival of this idiom nearly reaching the "dead language" status. This is what we can regard as the swan song of Sephardi, namely its return to society, not as an instrument of communication, but solely as musical compositions text. The quotation in the title clearly indicates the status of this idiom even for the representative soloists of the Sephardi community. The author envisages the manner in which the soloists relate to the language, as indicated in the interviews and press articles, as well as the impact of these texts of musical compositions upon the Sephardi community, since the language becomes an identification factor for the community at a socio-cultural level, despite the text being incomprehensible (p. 202203).

A sociolinguistic contribution is also provided by Elton Prifti, Das Italienische der italoalbanischen Migranten in den USA zwischen Schriftlichkeit und Mündlichkeit (p. 347-366), although with an emphasis on the linguistic characteristics of the targeted linguistic community, the study analyzing a linguistic variation proper. The article also discusses the phonetic and phonological (as well as orthographic), morphological and lexical particularities along with the variants of Italian that the language of the respective community is based on.

Three contributions are of a lexicological nature. One is dedicated to the Ottoman food terminology preserved within the European area (Wolfgang Schweickard, «vr'o capama, vr'o paclava, vr'o ciulama». Sprachliche Reflexe der osmanischen Küche in Europa, p. 221-233). The second, placed at the end of the section, is dedicated to the Albanian terminology for railway transportation, with a special focus on the language level in which it functions (Henry Ludwig, Zur Korrelation zwischen Infrastruktur und Sprache: Die albanische Eisenbahn und ihre gemeinsprachliche Terminologie, p. 377-395). The third deals with the terminology for pastoralism in the Southern Alps (Werner Forner, Nomenklaturen der Weidewirtschaft in den Südalpen, p. 235-264), where the dialects of 
the regions of Piedmont, Western Liguria and the Campagne area in Nice get in contact. The author performs an excellent analysis of the pastoralism terminology, taking into account factors of influence such as the prestige of the idiom, the area of influence, the itineraries for the transhumance movements and the period of rest in the pastoral area, the trips in the coast areas for the sale of products, as well as the migration caused by economic difficulties in certain periods. Although the idioms for the three area clearly differ in terms of vocabulary and grammatical system, the author notices that the terminology of pastoralism is common not due to the contact, but due to the common terminology of the idioms. The article, displaying the highest scientific level and impecable methodology provides a model to follow for any such research.

The topics of the other contributions in this section are: an unedited letter of Miklosich, a digital version of Romansh chrestomathy, racist tendencies in marketing strategies, the linguistics of populist discourse in an interview with Marine Le Pen (Franz Lebsanft), Spanish verbal periphrases in the contemporary discourse, Haitian Vodou vocabulary (p. 325-345) and the issue of language standardization in the Balkans, a case study of the Macedonian language.

The third part of the volume reunites the contributions in the fields of cultural studies and literature, most authors being either colleagues or students and doctoral disciples of the one rendered homage to within DFG-Graduiertenkolleg 1412 "Kulturelle Orientierungen und gesellschaftliche Ordnungsstrukturen in Südosteuropa" of the "Friedrich Schiller" University of Jena. Incidentally or less incidentally, many of the articles are (also) related to the Romanian space.

The first article of the section, Überlegungen zur Region als begrifflichem Instrument (p. 399-412), is situated on a general plan. The author, Michael Metzeltin, provides an analysis of the factors-of a geographic, economic, cultural, historic or linguistic nature-that lead to the concept designated by the term "region", an important instrument in the contemporary European politics, constantly used in the political powers environment of all times, even if it had different linguistic manifestations, as the author indicates in the beginning of the article.

In Die Adressanten und Auftraggeber von
Cantemirs Schriften (p. 413-426), Klaus Bochmann presents Dimitrie Cantemir's work from a double perspective: the recipient and receiver. The complexity of Cantemir's work, the languages his works were written in, the cultural-geographic areas he was interested in, his pioneering role on several levels are aspects that invite to further such studies on this writer's works. The contributions of Dragos Moldovanu can be of great interest for readers interested in the linguistic and cultural topics related to Cantemir's works.

Another Romanian author who is approached in this third section is Mircea Eliade, with his metaliterary / self-referrential novels Intoarcerea din rai [Return from Paradise] and Huliganii [The Hooligans] (p. 441-454).

Christina Vogel performs a comparative analysis between the aesthetic conception of Benjamin Fondane-Romanian-born French writer of Jewish origins-and the French speaking Swiss writer Charles Ferdinand Ramuz, in the article Benjamin Fondane et C.F. Ramuz: une rencontre insolite au sein de l'espace francophone (p. 589-599). Fodane's views on language and his esthetic principles in literature and film are analalyzed in connection to those of Ramuz through an element belonging to the world of cinema: the movie Rapt (1933), a screening of Ramuz's novel $L$ a Séparation des races, whose adaptation for cinema and script belong to Fondane.

In the article Ritter Pfefferkorn und die wunderbare Empfängnis (p. 539-557) Gabriella Schubert approaches, in an Eastern and South-Eastern context, the popular creation Pipăruş Petru și Florea Inflorit, issued in Povești ardeleneşti [Tales from Ardeal], collected by Ion Pop-Reteganul. In her study entitled Der Vampir in der südslawischen und rumänischen Volksdichtung (p. 559-588), Petra HimstedtVaid gathers enough evidence to prove that an element usually associated with the Romanian space, and more exactly the Transylvanian one-namely the vampire-has a Balkan status due to its presence in the folk creations of Southern Slavians (in Bulgaria and the area of former Yugoslavia).

With Ein Thüringer Schuster im Banat: Johann Caspar Steube (p. 497-511), Victoria Popovici rehabilitates a travel literature author and manages to extract an ethnographic and linguistic image of Banat at the end of the $18^{\text {th }}$ century from one of his works issued in 1791: Wanderschaften und Schicksale. 
Based on a corpus extracted from the webpages of a few important German journals and certain European or German institutions, Esther Quicker conducts a contemporary imagology study on Romania (2014) seen as both in terms of a country (touristic area, prince Charles, Dracula, food culture and also perceived as a space of massive immigration, Moldova as part of Romania, level of work qualification, Ion Antonescu, corruption, gypsies) and of a culture (The Enescu Festival, Brâncuși, literatureprose and theatre-, opera, the cinema industry, Romanians' proficiency in foreign languages). According to the data collected in 2014, the Germans used to associate Romania with rather negative realities, "despite Romania's beauties" (p. 471), as stated by the author, an excellent connoisseur of both Romanian language and realities, as also indicated by the final paragraph of her contribution (p. 455-474).

Martin Jung depicts the perception upon the Jewish minority in Romania from the perspective of Romanian museums (p. 475-496). The issue of anti-Semitism, as Martin Jung rightfully remarks, is "a dark chapter" in the history of Romania, yet it cannot distort the general attitude of Romanians towards foreigners, regardless of their nationality. The author of the study entitled «Romanii verzi»? Museale Selbst-, Fremd-und Geschichtsbilder der jüdischer Minderheit in Rumänien proves, with his remarks, to be a subtle and responsible researcher. We quote his final statement that reflects the reality of this issue in Romania: "Angesichts der hier nur angerissenen strukturellen, inhaltlichen und gestalterischen Übereinstimmungen mit der rumänischen Geschichtskultur erweisen sich die Juden in $\mathrm{Ru}$ mänien als Românii verzi, als wahre Rumänen [Taking into account the structural, content, as well as artistic congruities-merely outlined here-with the Romanian collective memory, the Romanian Jews prove to be români verzi, true Romanians]".

Ksenija Cronomarković and Aleksandra Salamurović provide an analysis of the way in which the 1989 Romanian revolution was reflected in the printed press in Yugoslavia (p. 679-701), focusing on discursive, denominative and predicative strategies, metaphorical speech and emotion recognition marks. A subchapter of the study accounts for the testimonies of Yugoslavian press representatives regarding the way they were treated by Romanians (p. 687-691).
An issue extensively discussed by Romanian ethnics, namely the issue of Moldova between Prut and Dniester, is approached from a totally new perspective by Jennifer R. Cash in Who is a Real Russian? Revisiting the Moldovan Question (p. 725-741). With deep knowledge of the Republic of Moldova issue from a social anthropological perspective, the author accounts for the status of Russian ethnics or people regarded as Russians in the Republic of Moldova, starting from various census records, the language of education in primary and secondary school, linguistic contacts and interethnic relationships at various social levels.

Hendrik Kraft (p. 427-439) attempts at identifying the reasons for which the "manele", basically sung by gypsy ethnics, are frowned upon in Romania although, according to the author, they are extremely popular. The explanations would have been different had the author made the difference between their popularity and the visibility resulting from irresponsible public behaviour or if he had identified the social area where this music is popular as well as the percentage of the respective social segment in Romania. A clue for such an erroneous perception is the identification of the Romanians with the gypsy emigrants from Romania, an unfortunate confusion also resulting from the endonym rrom, perceived as politically incorrect within both the Romanian and the gypsy societies (with the few exceptions of those gypsies who are involved politically). The gypsies identify themselves with the endonym tsigan and use the prolific lexical family of this term extensively in their speech.

The other eight articles included in this third section are not related directly or are not related at all to Romania or the Romanian spece. In the article Kruševo, die Aromunen und das Makedonium (p. 513-537), Joachim von Puttkamer retraces the historical context and describes the role of Aromanians in the emancipation action from the Turkish authority which lead to the proclamation, in august 1903, of the short-lived Kruševo Republic established in the Macedonian town of Kruševo, in which the Aromanians had an important demographic percentage, representing the majority, according to the information provided by Gustav Weigand. Related topic-wise to the study of von Puttkamer is the contribution of Peter Mario Kreuter, The Flâneur of Salonica. The First Balkan War in the Private 
Correspondence of George I, King of Hellenes with Fritz Peter Uldall (1847-1931) (p. 761-777). In Eastern Orthodox and Western Latin Churches under Communism: Differences and Parallels (p. 703-723), Vasilios Makrides analyses the relations between Christian churches and the communist regimes in Eastern and South-Eastern Europe. In Cervantes, die Novelle und die Entstehung des Quijote (p. 601-611), Harald Wentzlaff-Eggebert attempts at proving that Cervantes' novel was initially conceived as a shortstory. Christine Felbek and Andre Klump offer a detailed account of the importance of the theatre in the dissemination of Ladin language and culture in Southern Tyrol (p. 613-652). Andrea Meyer-Fraatz analyses the reception of Jacques Brel at the Croatian "singer- songwriter" Arsen Dedić (p. 653-677). Silvia Petzoldt provides an analysis of the novel One
Woman in the War by Hungarian writer Alaine Polcz, with an emphasis on the autobiographical references, mainly on the sexual violence against women during the war.

In the final article of the volume, Die weiche Seite des Ali Pasha: der Löwe von Epirus und seine Vorliebe für Musik (p. 779-795) the authors, Wolf Dietrich and Thede Kahl, emphasize a less known perspective upon Ali Pașa, namely his passion for music, a quality harder to detect in the one known as The Lion of Epirus, famous for his legendary brutality.

The volume, containing a diversity of topics, brings homage to professor Wolfgang Dahmen, not only by being dedicated to him, but also due to its valuable contributions, especially considering that many of the authors were his students or doctoral disciples. 